(5) The accuracy and general utility of the proposed methods have been proven, as shown by Series XII of the Test Experiments.

MEADVILIE, PA.

\title{
THE INFLUENCE OF CHLORINE ON THE DETERMINATION OF NITRATES BY THE PHENOL DISULPHONIC ACID METHOD.
}

By Robert Stewart and J, E, Greaves.

Received March 22, 1913.

The question involved in this study is of fundamental importance in the determination of nitrates in cultivated soils of the arid west, which may be impregnated with alkali. Earlier work ${ }^{1}$ at this laboratory on this question demonstrated a marked influence of chlorine upon the amount of nitrates found. Thus, it was found that if the soil solution contained even as low a concentration as 2.6 parts per million of chlorine in the soil extract less nitrates were found by this method than were actually present.

The experimental data recently presented by Lipman and Sharp, ${ }^{2}$ although they are apparently not aware of this fact, confirm this conclusion. This may be seen by converting the results obtained in both cases to the same basis in order to make a comparison, since our results are reported as parts per million of chlorine in the soil extract, while Lipman and Sharp's results are reported as milligrams of sodium chloride present.

The results converted to the same basis, i. e., milligrams of sodium chloride actually present in the portion of the solution used are compared in Table I.

Table I.-Influence of Ionic Chlorine on the Determination of Nitrates in SOlution.

By Stewart and Greaves.

\begin{tabular}{|c|c|c|c|c|c|c|c|}
\hline \multirow[b]{2}{*}{$\mathrm{Mg} . \mathrm{NaCl}$} & & \\
\hline & ${ }_{\text {added. }} \mathrm{N}^{2}$ & $\begin{array}{l}\text { N. N. } \\
\text { found. }\end{array}$ & $\begin{array}{l}\% \text { N. N. } \\
\text { found. }\end{array}$ & $\mathrm{NaCl}$. & $\begin{array}{l}\mathrm{N} \cdot \mathrm{N} \text {. } \\
\text { added. }\end{array}$ & $\begin{array}{l}\text { N. N. } \\
\text { found. }\end{array}$ & $\begin{array}{l}\% \mathrm{~N} . \\
\text { found. }\end{array}$ \\
\hline 0.04 & 0.01 & 0.01 & 100 & 0.01 & 0.05 & 0.051 & 102 \\
\hline 0.09 & 0.01 & 0.01 & 100 & 0.05 & 0.05 & $0.05 \mathrm{I}$ & 102 \\
\hline 0.13 & 0.01 & 0.01 & 100 & 0.10 & 0.05 & 0.049 & 98 \\
\hline 0.27 & $0.0 I$ & 0.009 & 90 & 0.25 & 0.05 & 0.045 & 90 \\
\hline $0.5^{2}$ & $0.0 \mathrm{I}$ & 0.0094 & 94 & 0.50 & 0.05 & $0.04 I$ & 82 \\
\hline 0.79 & $0.0 \mathrm{r}$ & 0.0086 & 86 & 1.00 & 0.05 & 0.035 & 70 \\
\hline
\end{tabular}

Thus, it may be readily seen that when only o.I mg. of sodium chloride was present in both cases all of the nitrates present could be easily determined. Lipman and Sharp, however, found that when $0.25 \mathrm{mg}$. of sodium chloride was present that only $90 \%$ of the nitrates actually present could be determined while we found that when $0.27 \mathrm{mg}$. of sodium chloride was present, only $90 \%$ of the nitrates could be found. With a concentration of I mg., Lipman and Sharp found only $70 \%$ of the nitrate, while we, with $0.79 \mathrm{mg}$. of sodium chloride, found only $86 \%$

${ }^{1}$ Stewart and Greaves, This Journal, 32, 756 (19ro).

${ }^{2}$ Univ. of Cal. Publication in Agr. Sci., I, I2 (1912). 
of the nitrate. It is thus seen that Lipman and Sharp have confirmed, in a remarkable manner, the results obtained at this laboratory. It is seldom that investigators in separate laboratories get such concordant results. It is thus fully confirmed that ionic chlorine has a marked influence on the determination of nitrates in the soil extract and that in alkali soils this fact must be taken into consideration in determining the nitrate content.

There is still another phase of this question, however, one which so far as. we are aware has never been considered by previous investigators and this is the influence of chlorine, which is not in the ionic form but is combined in the organic molecule, on the determination of the nitrate content of the soil extract. This is a question of considerable practical importance, since chloroform is frequently used to inhibit the action of bacteria in the soil extract. Especially is this so in case of the use of the lime method as. proposed by Lipman and Sharp. In the use of this method, if chloroform be also used, it appeared to ts that there is the possibility of the formation of ionic chlorine from the organic chlorine of the chloroform and if present in sufficient quantities this would materially affect the value of the results obtained. The assumption that ionic chlorine would be formed by the action of calcium oxide on the chloroform seemed to be justified by the fact that is so well known that potassium hydroxide does act on chloroform as indicated in the following equation: $\mathrm{CHCl}_{3}+\mathrm{KOH}=$ $\mathrm{HCOOK}+3 \mathrm{KCl}+2 \mathrm{H}_{2} \mathrm{O}$ with the production of ionic chlorine. This being the case why may not calcium hydroxide act in a similar manner, as follows: $2 \mathrm{CHCl}_{3}+{ }_{4} \mathrm{Ca}(\mathrm{OH})_{2}=(\mathrm{HCOO})_{2} \mathrm{Ca}+{ }_{3} \mathrm{CaCl}_{2}+{ }_{4} \mathrm{H}_{2} \mathrm{O}$ ?

If such a reaction did take place, the ionic chlorine formed would. materially interfere with the determination of the nitrates. In view of the fact that we are aware that chloroform is used by some investigators with the lime method, it appeared to us that the question should be exhaustively studied.

Therefore, varying amounts of chloroform were added to solutions containing I mg. of nitric nitrogen and I gram of lime. These solutions. were carefully worked up in a mortar, placed in a closed container, and allowed to stand over night. A portion of the solution was used the next morning to determin the ionic chlorine present, while in another portion the nitric nitrogen was determined. The results obtained are given in Table II.

An examination of the data presented in Table II brings out two very important facts. First, that ionic chlorine is liberated when lime and chloroform are mixed together and that the quantity of chlorine liberated varies with the chloroform. Second, that the ionic chlorine formed interferes very greatly with the accurate determination of nitrates by the phenol disulfonic acid method. It may, therefore, be seen that deter- 
minations made by this method, where the solution has both chloroform and lime present, give results which may be less than one-half of what they should be.

TABle II.-INFLuence of Chloroform on Determination of the Nitric Nitrogen BY THE LIME METhOD.

$\begin{array}{ccccccc}\begin{array}{c}\text { Sample } \\ \text { No. }\end{array} & \begin{array}{c}\text { Lime } \\ \text { added. }\end{array} & \begin{array}{c}\text { Chloroform } \\ \text { added. } \\ \text { Cc. }\end{array} & \begin{array}{c}\text { Nitric nitro- Nitric nitro- } \\ \text { gen added. } \\ \text { Mg. }\end{array} & \begin{array}{c}\text { gen found. } \\ \text { Mg. }\end{array} & \begin{array}{c}\text { Per cent. } \\ \text { loss. }\end{array} & \begin{array}{c}\text { Ionic chlorine } \\ \text { found, mg. } \\ \text { sodium chloride. }\end{array} \\ \text { I } & \text { I.O } & \text { none } & \text { I.O } & \text { I.O } & \text { none } & \text { none } \\ 2 & \text { I.O } & 0.1 & \text { I.O } & 0.54 & 46 & 2.0 \\ 3 & \text { I.O } & 0.2 & \text { I.O } & 0.37 & 63 & 5.2 \\ 4 & \text { I.O } & 0.3 & \text { I.O } & 0.47 & 53 & 8.6 \\ 5 & \text { I.O } & 0.4 & 1.0 & 0.24 & 76 & 11.4 \\ 6 & \text { I.O } & 0.5 & 1.0 & 0.23 & 77 & 12.8 \\ 7 & \text { I.O } & 0.6 & 1.0 & 0.37 & 63 & 16.3 \\ 8 & \text { I.O } & 0.7 & \text { I.O } & 0.44 & 56 & 26.3 \\ 9 & \text { I.O } & 0.8 & \text { I.O } & 0.32 & 68 & 32.0 \\ \text { IO } & \text { I.O } & 0.9 & 1.0 & 0.40 & 60 & 37.9 \\ \text { II } & \text { I.O } & \text { I.O } & \text { I.O } & 0.40 & 60 & 41.3\end{array}$

As a further check on the influence of chloroform on the determination of nitric nitrogen, a great number of determinations were made on solutions containing varying amounts of nitric nitrogen, both with and without the addition of chloroform. In the case where chloroform was added, a few drops were shaken into the solution, just as is the case where it is added to prevent bacterial action while the solution is standing. The results are given in Table III.

Table III.-Determination gy Lime Method of Nitric Nitrogen Present in Solution to which KNown Amounts of Nitrate was AdDed.

$\begin{array}{ccccccc}\begin{array}{c}\text { Sample } \\ \text { No. }\end{array} & \begin{array}{c}\text { Nitric } \\ \text { nitrogen } \\ \text { added. } \\ \text { Mg. }\end{array} & \begin{array}{c}\text { 1st trial. } \\ \text { Mg. }\end{array} & \begin{array}{c}\text { 2nd trial. } \\ \text { Mg. } \\ \text { Without chloroform. }\end{array} & \begin{array}{c}\text { 3rd trial. } \\ \text { Mg. }\end{array} & \begin{array}{c}\text { 4th trial. } \\ \text { Mg. }\end{array} & \begin{array}{c}\text { Average. } \\ \text { Mg. }\end{array} \\ \text { I } & \text { none } & \text { none } & \begin{array}{c}\text { Nitric nitrogen found. } \\ \text { none }\end{array} & \text { none } & \text { none } & \text { none } \\ 2 & 1.0 & 0.88 & 0.90 & 1.0 & 0.82 & 0.90 \\ 3 & 1.5 & 1.5 & 1.50 & 1.53 & 1.43 & 1.49 \\ 4 & 2.0 & 2.0 & 2.0 & 2.05 & 2.00 & 2.01 \\ 5 & 3.0 & 3.0 & 3.05 & 3.2 & 3.15 & 3.10 \\ & & & \text { With chloroform. } & & \\ \text { I } & \text { none } & \text { none } & \text { none } & \text { none } & \text { none } & \text { none } \\ 2 & \text { I.0 } & 0.29 & 0.32 & 0.40 & 0.55 & 0.39 \\ 3 & 1.5 & 0.52 & 0.70 & 0.63 & 0.78 & 0.66 \\ 4 & 2.0 & 0.84 & \text { I.10 } & 0.92 & 1.08 & 0.99 \\ 5 & 3.0 & 0.69 & 1.20 & 1.15 & 1.52 & 1.14\end{array}$

These results show conclusively that in the absence of chloroform concordant results were obtained by this method and that practically all of the added nitrate could be accurately recovered. When, however, chloroform was added to the solution containing the nitrate and calcium hydroxide, it was impossible to obtain concordant results and the amount 
of nitric nitrogen found had no apparent relationship to the amount of nitric nitrogen actually present. It may thus be seen that the chloroform in the presence of calcium hydroxide very materially interferes with the accurate determination of the nitric nitrogen.

The discussion so far has had to do only with the determination of the nitrates in solution. The soil factor must be considered. Accordingly, it was decided to determin the nitric nitrogen content in two soils, one a very rich, hothouse soil, the other a field soil, poor in nitric nitrogen. The nitric nitrogen was determined by the lime method both with and without chloroform. The results obtained are recorded in Table IV.

Table IV.-Comparative Determination of Nitric Nitrogen in a SoIl.

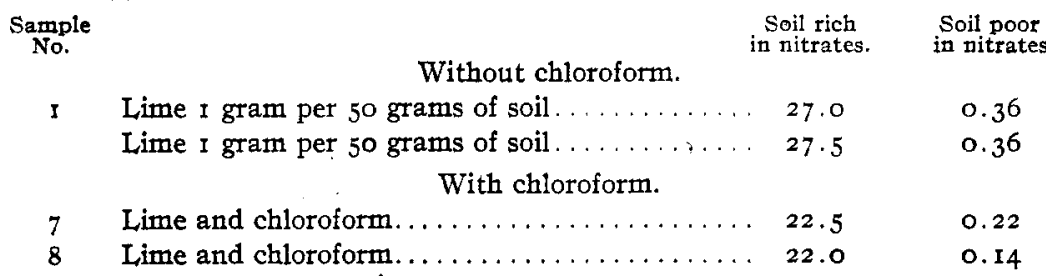

Again the marked influence of chlorine is demonstrated. In the rich soil where chloroform and lime are used, there is a loss of $5 \mathrm{mg}$. of nitric nitrogen, while in the soil poor in nitric nitrogen there is a loss of over $50 \%$ of the nitrates, and furthermore, the results obtained are not concordant.

It is seen, therefore, that the lime method is highly desirable for use in soils rich in nitrates and organic matter, since a clear solution is thus obtained and there is no interference in the determination of the nitrates, provided chloroform is not also used.

Ionic chlorine has a marked influence on the determination of the nitrates in the solution whether the ionic chlorine is derived from the chlorides of the soil or by decomposition of the added chloroform. The result obtained also indicated clearly that chloroform should not be added to the soil extract obtained by the lime method.

Utah Experiment Station, Logan, Utah.

[CONTRIBUtIONS FROM THE SHEFFIELD LABORATORY OF YALE UNIVERSITY.]

\section{THE FORMATION OF $\beta$-KETONE ESTERS BY THE APPLICATION OF REFORMATSKY'S REACTION.}

By TREAT B. JoHnSON.

Received March 26, 1913.

In 1887 , Fittig and Daimler ${ }^{1}$ investigated the action of ethyl chloroacetate on diethyl oxalate in the presence of amalgamated zinc. They observed that this halide reacted with the oxalate, in an unique manner,

IBer., 20, 202; Ann., 249, 182. 